\title{
Erratum to protective effect of hydrogen sulfide on endothelial cells through Sirt1-FOX01 mediated autophagy
}

\section{Editorial Office}

Annals of Translational Medicine

Correspondence to: Editorial Office. Annals of Translational Medicine. Email: editor@atmjournal.org.

Submitted Jul 01, 2021. Accepted for publication Jul 21, 2021.

doi: 10.21037/atm-2021-20

View this article at: https://dx.doi.org/10.21037/atm-2021-20

Erratum to: Ann Transl Med 2020;8:1586

In the article entitled "Protective effect of hydrogen sulfide on endothelial cells through Sirt1-FoxO1-mediated autophagy" (1), the images of Figure 5B selected to represent the flow cytometric analysis of the apoptosis of HUVECs in Ox-LDL group and Ex-527 + GYY4137 + Ox-LDL group were duplicated incorrectly.

The revised version of Figure 5, containing the correct data for the Ex-527 + GYY4137 + Ox-LDL in Figure 5B, is shown below. This error did not significantly affect either the results or the conclusions of the paper. 

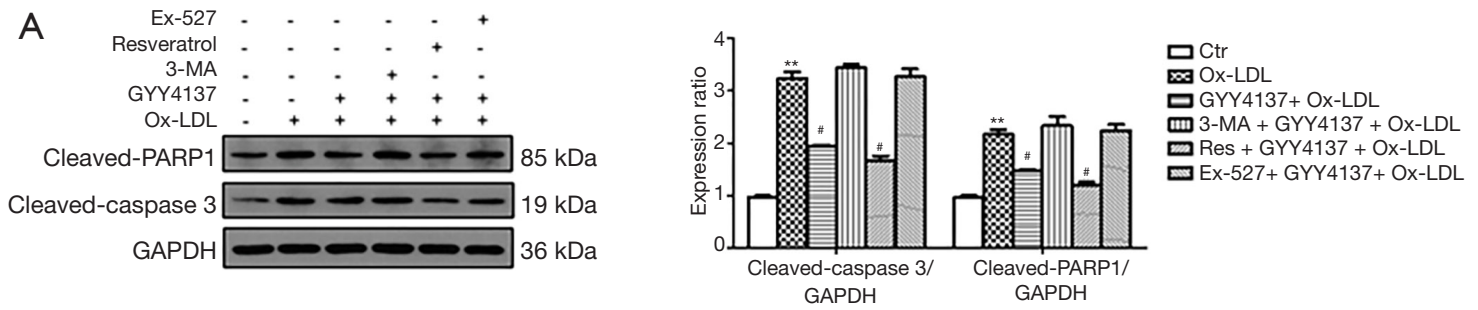

B
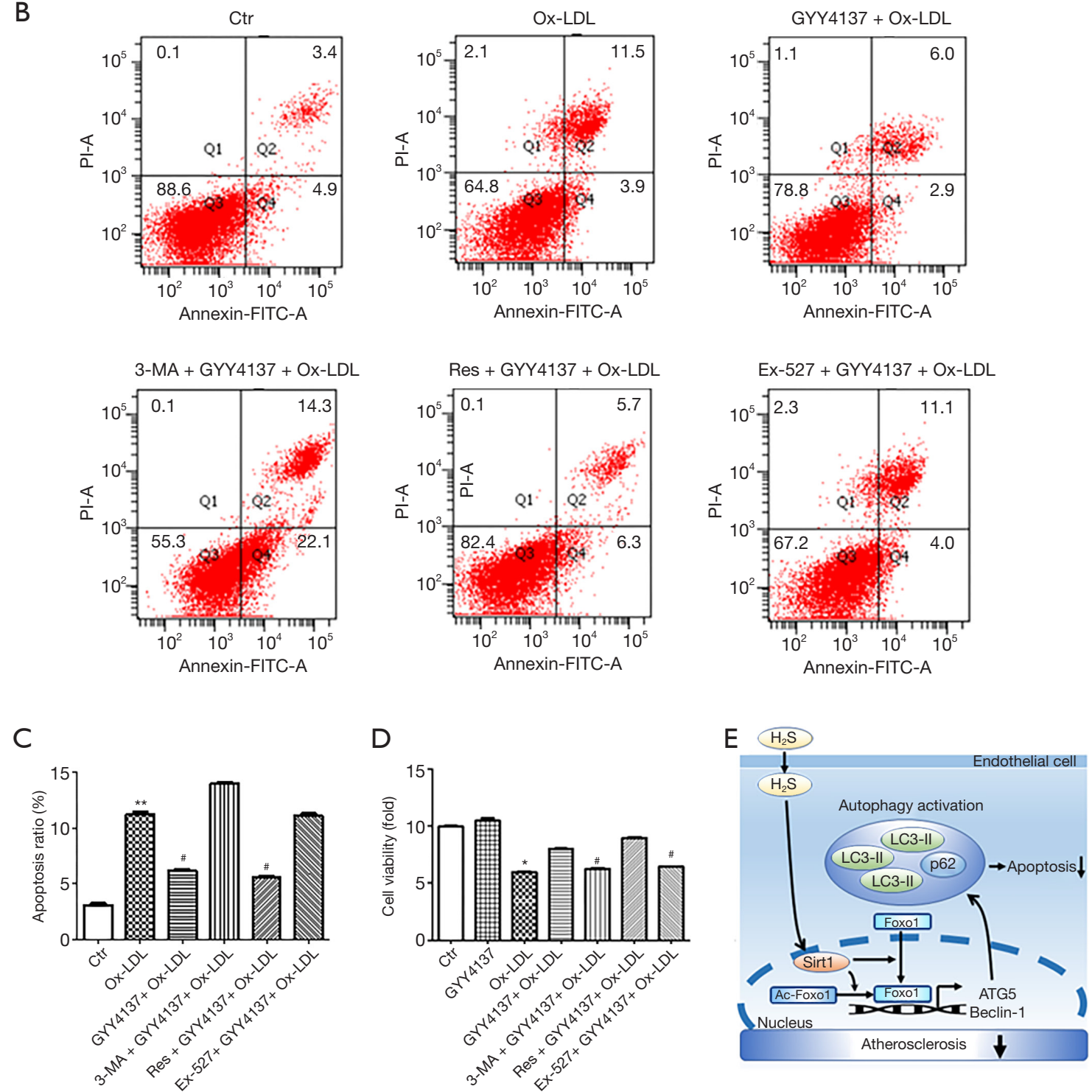

Figure $5 \mathrm{H}_{2} \mathrm{~S}$-induced autophagy via Sirt1 protects against Ox-LDL-induced apoptosis in HUVECs. HUVECs were pre-treated with or without 3-MA, resveratrol, Ex-527, and GYY4137 for the indicated times followed by treatment with Ox-LDL. (A) Immunoblot analyses showing cleaved-caspase- 3 and cleaved-PARP. Expression in control (Ctr) group cells was assigned a value of $1, \mathrm{n} \geq 3 .{ }^{* *} \mathrm{P}<0.01$ versus $\mathrm{Ctr}$, ${ }^{\#} \mathrm{P}<0.05$ versus $\mathrm{Ox}-\mathrm{LDL}$. (B,C) Flow cytometric analysis to detect the apoptosis of HUVECs. $\mathrm{n} \geq 3$. ${ }^{* *} \mathrm{P}<0.01$ versus Ctr, ${ }^{\#} \mathrm{P}<0.05$ versus $\mathrm{Ox}-$ LDL. (D) Cell viability was measured using the CCK-8 assay. Cell viability in control (Ctr) group was assigned a value of $1, \mathrm{n}=6 .{ }^{*} \mathrm{P}<0.01$ versus Ctr, ${ }^{\#} \mathrm{P}<0.05$ versus $\mathrm{Ox}-\mathrm{LDL}$. Data are expressed as the mean \pm SEM. (E) Schematic representation of the effects and mechanisms of $\mathrm{H}_{2} \mathrm{~S}$ on autophagy and apoptosis in HUVECs. 
Click here to view the updated version of the article.

Open Access Statement: This is an Open Access article distributed in accordance with the Creative Commons AttributionNonCommercial-NoDerivs 4.0 International License (CC BY-NC-ND 4.0), which permits the non-commercial replication and distribution of the article with the strict proviso that no changes or edits are made and the original work is properly cited (including links to both the formal publication through the relevant DOI and the license). See: https://creativecommons.org/ licenses/by-nc-nd/4.0/.

\section{References}

1. Zhu L, Duan W, Wu G, et al. Protective effect of hydrogen sulfide on endothelial cells through Sirt1-FoxO1-mediated autophagy. Ann Transl Med 2020;8:1586.

Cite this article as: Editorial Office. Erratum to protective effect of hydrogen sulfide on endothelial cells through Sirt1FOXO1 mediated autophagy. Ann Transl Med 2021;9(15):1282. doi: $10.21037 / \mathrm{atm}-2021-20$ 